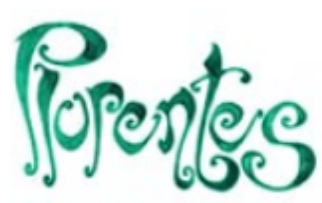

Artes y Letras
Plurentes. Artes y Letras

ISSN: 1853-6212

plurentesunlp@gmail.com

Universidad Nacional de La Plata

Secretaría de Asuntos Académicos

Prosecretaría de Asuntos Académicos

Bachillerato de Bellas Artes, "Prof. Francisco A. De Santo" Argentina

\title{
Dos pinturas (Poemas)
}

López Romero, Rodrigo

Dos pinturas (Poemas)

Plurentes. Artes y Letras, núm. 11, e017, 2020

Universidad Nacional de La Plata

Secretaría de Asuntos Académicos

Prosecretaría de Asuntos Académicos

Bachillerato de Bellas Artes, "Prof. Francisco A. De Santo"

Argentina

DOI: https://doi.org/10.24215/18536212e017

Atribución no comercial compartir igual (CC BY-NC-SA) 4.0 


\title{
Dos pinturas (Poemas)
}

\section{Rodrigo López Romero}

DOI: https://doi.org/10.24215/18536212e017

Universidad Autónoma del Estado de México, México gorodripolze@gmail.com

\section{Caravaggio, Cesto con frutas}

\begin{abstract}
Anzuelo a medias:
frutas maduras

hojas lustrosas

áreas marchitas

vida, vejez

lo tan deseado

y el ya muy tarde
\end{abstract}

Cerca, para que los dedos con solo estirarse

extirpen

una uva del racimo

y la sombra del cesto

parece acercarlo

cuando jamás

Dicen que un cardenal lloró al verla ¿una canasta pintada? quizás porque comprendió que moría y que uno no puede nunca comer un cesto de frutas [cuando mucho engullir un racimo o una pera] la canasta es una sintaxis imposible un espejo que no va a respondernos

Las hojas y ramas apuntan fuera como si el mimbre no bastara y lo cierto estuviera lejos del cuadro no en nosotros ni en el muro [en otra parte no preguntes]

\section{Caravaggio}

ha dejado una canasta sola ¿será que también vio su muerte? ¿que este énfasis es comprensión? las uvas oscuras conservan ese polvo azul y ni una mosca que las acose 
Es esta falta de mano, de mosca lo que nos repele como el pintor al saber que ni tragedias ni glorias sino sus iras

lo acabarían como cualquier puñal y la canasta es eso, la vida que ciega con su fulgor que provoca el hambre sin saciarnos

Por eso los turistas le toman fotos para que la pincelada no los alcance para no llorar en el entierro para no tener que responder a nada porque frente a un cesto de frutas pudo llorar un cardenal [si no es mentira] oun papa o el pintor o todos como pericos al ver manjares fuera de los barrotes sin nada que se los acerque

\title{
Domenico Gnoli, Hombre Con DOS ELEVACIONES, 1964
}

\author{
Adelante, atrás \\ tan simple como eso \\ pero en un traje a rayas \\ con corbata pañuelo \\ y nada asoma \\ o solo un poco de cuello \\ no importa \\ se trata de un hombre cualquiera \\ de quien responde despacha \\ sonrisa aprendida \\ línea directa firma sello \\ O es la víctima \\ el empleado subalterno a quien nadie nunca \\ da las gracias \\ ¿no lo revelan las manchas en la tela? \\ como humedad surgida de tanta indiferencia \\ o por el miedo que provoca un sudor frío, \\ lento cansado de sí mismo \\ el vestigio de un cuerpo \\ al que el escritorio ha encorvado y vuelto grueso \\ Un pecho una espalda \\ en un traje que se ha adherido al cuerpo \\ como un paréntesis \\ pero la corbata tiene mariposas \\ y es corta como si quisiera reírse \\ decirnos que nunca fue en serio \\ solo un signo más
}


tela cortada

ninguna tragedia en absoluto

Es un retrato menos el retrato

credencial sin foto

una placa para verse en microscopio

el pintor disfruta de trabajar secciones

hacer perder los rasgos

nos recuerda

que la visión es un periscopio viciado

un plano recortado sin cuidado

una censura

Al final sigue la pregunta:

¿cómo es su rostro

marcado por qué ceño?

¿será una mandíbula atroz de perro

una sonrisa franca

o la tímida resignación de un hombre?

\section{BY-NC-SA}

